\title{
OVERVIEW OF BASIC SCIENTIFIC APPROACHES \\ TO EVALUATION OF THE DEVELOPMENT \\ STRATEGIES EFFICIENCY
}

\section{ОГЛЯД ОСНОВНИХ НАУКОВИХ ПІДХОДІВ ДО ОЦІНКИ ЕФЕКТИВНОСТІ СТРАТЕГІЙ РОЗВИТКУ}

\section{Oleksandra Kononova ${ }^{1}$}

DOI: https://doi.org/10.30525/978-9934-588-15-0-33

Abstract. In the current environment, one of the defining aspects of the economic systems functioning (enterprises, industries, economics) is the choice of directions of development, which is developed and substantiated at a strategic level within a certain entity. The need for the most appropriate and optimal choice of development strategies is actualized by the continuous influence of the environment, which is changing in the 21 st century. At a more rapid pace, it has complex enough manifestations related to the new globalization, information and communication challenges. In particular, as markets become more open, leaders in one or the other domestic markets, including in the construction industry, may cede and lose competitive positions to new, innovative companies that have more adaptive, flexible development strategies. The definition of a certain range of development strategies that will be substantiated in the future is related to the need to understand their types, classifications by different characteristics. In this area there is a wide range of scientific intelligence, they need to be clearly systematized and distinguished provisions that will formulate a unified approach to possible types of strategies for economic systems, depending on one or other features, their characteristics, etc. The problem of determining the basic scientific approaches to the evaluation of the effectiveness of strategies for the economic entities development has been addressed by many scientists: G. Mintzberg, M. Porter, K. Deception, K. Freeman, B. Tweiss, O. Vodachkova, B. Santo, V. Savchuk and others. It should be noted that the authors do not have a single unified approach to assessing the effectiveness

\footnotetext{
${ }^{1} \mathrm{PhD}$, Associate Professor,

Prydniprovska State Academy of Civil Engineering and Architecture, Ukraine

(C) Oleksandra Kononova
} 
of development strategies of business entities, which led to the conclusion of the need to develop an author approach. The appropriateness, soundness of implementation and use of development strategies is determined by their effectiveness with respect to the status and level of certain performance indicators of the subjects of the construction industry. The validity, completeness and complexity of assessing the development strategies effectiveness can be assessed by applying strategic, relevant, science-based methodological approaches to specific areas of strategic analysis. Scientific works use a wide range of approaches to systematically and locally examine the effectiveness of development strategies for both the industry and its subjects. The content and characteristics of these approaches determine their methodology, advantages, disadvantages, and the possibility of universal application to study the problem of evaluating the effectiveness of development strategies.

\section{1. Ветуп}

Трансформації підходів до теоретичного, методичного забезпечення щодо оцінки стану та динаміки ефективності стратегій розвитку економічних суб'єктів певних галузей передбачають отримання більш достовірних, всебічних результатів та характеристик досліджуваного напрямку з урахуванням сучасних тенденцій. Поява нових підходів стосовно зазначеної проблематики в будівельній галузі може сприяти кращому вивченню стратегічного розвитку, виявити ті проблеми, які не були зрозумілими, коли використовувались традиційні варіанти оцінки ефективності функціонування підприємницьких структур.

Особливостям підходів до оцінки ефективності стратегій розвитку присвячено публікації зарубіжних і вітчизняних економістів, серед яких праці І. Ансоффа, Л.П. Артеменко, В.Ю. Божанової, В.Т. Вечерова, Л.С. Довгань, О.С. Кононової, Г. Мінцберга, 3.С. Шершньової та інших. Завдяки їх дослідженням стає можливим використання теоретичних основ стратегічного управління та ефективності стратегій розвитку на практиці у пристосуванні до конкретних підприємств промисловості.

В рамках нашого дослідження була визначена методика аналізу основних наукових підходів до оцінки ефективності стратегій розвитку, яка створена на підставі використання методу систематизації та порівняльного аналізу. Представлена методика передбачає виділення 
та огляд основних наукових підходів до оцінки ефективності стратегій розвитку будівельної галузі.

Для вивчення можливості застосування існуючих наукових методичних підходів, виявлення потреб адаптації або необхідності розробки, визначення якісно нових методів, показників оцінки потрібно проведення комплексного дослідження наукової бази за вказаним напрямком.

Метою даного дослідження є аналіз характеристик, переваг та недоліків основних сучасних наукових підходів щодо питання оцінки ефективності стратегій розвитку суб'єктів будівельної галузі.

\section{2. Підхід на основі прогнозної оцінки виробничих, техніко-економічних, фінансових, соціальних показників розвитку суб'єкта галузі}

По-перше, можна відмітити найбільш розповсюджений науковий підхід, який передбачає здійснення прогнозної оцінки виробничих, техніко-економічних, фінансових, соціальних показників розвитку суб'єкта галузі. При цьому, така оцінка може бути представлена прогнозним аналізом досягнення кількісних результатів за певними сферами (фінансово-економічною, соціальною) або аналізом зазначених прогнозних показників в рамках інтегрального показника. Як свідчать матеріали наукових досліджень [2], даний підхід оцінки ефективності стратегій розвитку в більшості випадків передбачено здійснювати як на стадії створення аналітичних інформаційних джерел, які використовуються для прийняття управлінських рішень щодо вибору певних стратегій розвитку суб'єктів галузі, так і на апробаційному етапі (на певних стадіях впровадження стратегій розвитку для можливого коригування, наприкінці реалізації певного проекту, для порівняння планових показників із звітними тощо).

В розрізі першого наукового підходу можемо відмітити погляд О. Гудзь, О. Мусійовської [2] щодо схеми, визначення прогнозних та звітних показників ефективності функціонування суб' єктів галузі внаслідок реалізації стратегій розвитку. Вивчення змісту та характеристик підходу авторів показує, що їх методика щодо оцінки ефективності стратегії розвитку вбудована в загальний методичний підхід стосовно формування стратегічного управління суб'єктів діяльності, а саме: 
- прогнозна оцінка планується на етапі розроблення стратегії розвитку. Згідно із твердженням авторів, така оцінка здійснюється після стратегічного цільового орієнтування, визначення змісту та характеристики стратегії, проведення оцінки iї впровадження в умовах впливу факторів внутрішнього та зовнішнього середовища на розвиток суб'єктів досліджуваної галузі економіки, перед кінцевим вибором стратегії розвитку. Потрібно відмітити, що автори, скоріш за все, мають на увазі, але упускають акцент на тому, що кінцевий вибір передбачає представлення варіативного переліку стратегій на початковому етапі встановлення цілей розвитку суб'єкта галузі. Дослідники [2, с. 336] пропонують оцінювати ефективність стратегії розвитку суб'єкта галузі через розрахунок та аналіз інтегрального показника стану розвитку підприємства, який може бути представлений комплексом показників, які ідентифікують:

1) стан продукції (послуг) досліджуваного суб'єкта діяльності, i можуть бути представлені:

показниками якості продукції (послуг) суб'єкта галузі. Відповідно до бачення О. Гудзь, О. Мусійовської [2, с. 337], це може бути якісний (непараметричний) показник, що визначатиметься експертним методом, прогнозне зростання рівня якого свідчитиме про ефективність стратегічного вибору. На нашу думку, цей показник може бути оцінений також і через кількісні показники, для цього потрібно встановити досяжні оцінювані параметричні орієнтири. Вказане дозволить, по-перше, усунути фактори впливу суб' єктивності оцінки з боку залучених експертів, по-друге, буде більш наочним доказом ефективності, оскільки підтверджується об'єктивними кількісними доказами. На наш погляд, в рамках стратегічного прогнозування розвитку повинна бути встановлена межа, на яку потрібно орієнтуватись при впровадженні, на це автори не вказують, хоча саме по собі покращення якості слід розвивати за конкретним орієнтиром;

показником рівня експорту продукції (послуг) в загальному складі загального обсягу доходу (виручки) від реалізації продукції (послуг) досліджуваного суб'єкта галузі. Судячи з підходу авторів, цей показник має техніко-економічне навантаження і свідчить про експорту орієнтованість збуту підприємницької структури. Виходячи з авторського трактування, планове зростання вказаного показника свідчить про ефективність стратегії розвитку. Необхідно відмітити, що даний 
прогнозний показник $є$ кількісним, і щодо нього, потрібне чітке визначення межі зростання, яка може бути досягнута внаслідок впровадження стратегічного плану розвитку суб'єкта галузі;

показником рівня оновлення продукції (послуг) суб'єкта підприємництва, який визначається через відношення обсягу доходу (виручки) від реалізації нової продукції (послуг) до загального обсягу доходу (виручки) від реалізації продукції (послуг) досліджуваного суб'єкта галузі. Як і стосовно інших показників вказаної категорії, стосовно вказаного оціночного показника позитивним результатом впровадження планової стратегії вважається зростання рівня оновлення продукції (послуг) суб'єкта галузі. Відповідно, автори не вважають за необхідне прогнозувати рівень такого оновлення. Можемо констатувати, що в більшості наукових праць [13] при встановленні нормативних значень стратегічних показників розвитку суб'єктів господарювання вчені визначають планові межі тільки для фінансово-економічних показників, зокрема, обсягів доходу (виручки) від реалізації продукції (послуг), собівартості реалізації продукції (послуг); чистого прибутку тощо;

2) стан фінансової стійкості суб'єкта галузі і можуть включати, зокрема: показники поточної ліквідності, фінансової автономії (фінансової незалежності), фінансового ризику. В рамках підходу авторів прогнозні граничні значення показників фінансової стійкості визначаються на рівні традиційного наукового підходу, представленого в теорії фінансово-економічного аналізу;

3) стан виробничої стійкості та техніко-технологічного рівня суб'єкта галузі, планове зростання яких за відповідними показниками свідчить про ефективність стратегії розвитку;

4) стан рентабельності (прибутковості) діяльності суб'єкта галузі, який ідентифікує основні прогнозні результати впровадження стратегії. Автори, як і стосовно інших прогнозних показників, не визначають нормативного рівня рентабельності, встановленого на стратегічному рівні. Вказане свідчить про те, що автори не вказують на потребу чітких цільових орієнтирів стратегічного планування, що, на нашу думку, свідчить про можливість декларативного підходу до розробки стратегії розвитку суб'єкта галузі. Прогнозування показників рентабельності реалізації стратегії суб'єкта господарювання на певному рівні дозволяє функціонувати в рамках визначених параметричних показників; 
5) стан соціального розвитку (ефективність управління кадрами) та рівень інформаційного забезпечення, прогнозне збільшення яких за визначеними показниками демонструє, згідно з підходом авторів [2, с. 338], ефективність стратегії розвитку.

- звітна та порівняльна оцінка планується на етапі апробації, стадії постійного моніторингу впровадження стратегії розвитку. Відповідно, вказаний етап дозволяє виявити певні відхилення від прогнозних орієнтирів стратегічного курсу розвитку, розробити адаптаційні заходи щодо модифікації стратегії та реалізувати їх, забезпечуючи подальший безперервний моніторинг дотримання планів та змін в реалізації.

Можемо констатувати, що представлена О. Гудзь, О. Мусійовською [2] методика оцінки ефективності може характеризуватись як динамічна та оптимізаційна. В рамках деяких наукових підходів не визначається етап постійного моніторингу, внесення коригувальних змін, а концентрується увага лише на визначенні прогнозних показників основних категорій (фінансової, соціальної, техніко-економічної, виробничої тощо).

Важливим аспектом наукового дослідження О. Гудзь, О. Мусійовської [2] є визначення шкали, яка дозволяє ідентифікувати стратегію розвитку суб'єкта галузі в залежності від значень основних оціночних (прогнозних та фактичних показників). Зокрема, за цією шкалою можна провести експрес-оцінку типу стратегії розвитку (ідентифікувати тип запланованої та реалізованої стратегії в залежності від традиційного наукового поділу, який може бути представлений, згідно з підходом авторів, захисною (значення інтегрального показника стану розвитку підприємства на рівні від 0 до 0,4), пасивно-наступальною (значення інтегрального показника стану розвитку підприємства на рівні від 0,41 до 0,73), стратегією ринкової ніші (значення інтегрального показника стану розвитку підприємства на рівні від 0,74 до 0,86), активно-наступальною стратегією (значення інтегрального показника стану розвитку підприємства на рівні від 0,87 до 1)). В багатьох наукових працях [14; 15] значення інтегрального показника розвитку оцінюється на рівні від 0 до 1, при цьому вказується, що 1 характеризує високий рівень розвитку підприємства, відповідно і високі стратегічні орієнтири. При цьому, не зустрічається категоризація шкал ефективності в залежності від типів стратегій розвитку, наведена в дослідженні О. Гудзь, О. Мусійовської [2]. 
Незважаючи на те, що суб'єкт галузі може мати стратегію розвитку, яка за типом та характеристиками відмінна від традиційних класифікацій, наприклад, інноваційну локальну стратегію розвитку, iї можна ідентифікувати в залежності від вказаного авторського підходу і визначити загальний характер функціонування, відповідність декларативного прогнозування фактичним звітним даним. Також, на нашу думку, такий підхід може бути адаптований до конкретної стратегії розвитку суб'єкта підприємництва. Відповідно, подана авторами категоризація стратегій розвитку в залежності від шкал ефективності рівня функціонування суб'єкта є актуальним науковим аспектом щодо дослідження зазначеного питання. Цей підхід може бути використаний в подальшому при розробці авторського підходу до обгрунтування методики оцінки ефективності стратегії розвитку.

Відповідно до загальних положень першого наукового підходу можна проаналізувати методику Ю. Бойко [1], яка передбачає використання універсального показника, що дозволяє враховувати як фінансові, так і нефінансові оціночні критерії ефективності впровадження стратегії розвитку на підприємстві. Згідно з твердженням автора, актуальною особливістю зазначеної методики є можливість порівняння інтегральних показників стратегічного планування щодо кожної розробленої стратегії розвитку, на основі чого можна обрати оптимальний варіант стратегічного розвитку суб'єкта галузі. Також, як відмічає дослідник, його розробка дозволяє за умов вихідних даних стратегічного розвитку конкурентів здійснювати порівняльний аналіз стратегій розвитку суб'єктів галузі. В складі ключових оціночних параметрів обрано чотири рівні аналізу, зокрема, перший передбачає оцінку загального рівня ефективності прогнозної стратегії, другий - оцінку рівня відповідності умовам зовнішнього середовища, конкурентних переваг, показників ефективності функціонування суб'єкта галузі, третій - оцінку ефективності за основними напрямками реалізації стратегії на прогнозному рівні, четвертий - аналіз ефекту покращення якості продукції (послуг) в рамках впровадження стратегії, ефекту впливу зовнішніх та внутрішніх факторів в рамках впровадження стратегіï. Відповідно до авторського підходу, на кожному оціночному рівні визначається комплексний показник, розраховується інтегральний показник ефективності за вказаними комплексними показниками. Слід 
відмітити універсальність зазначеного методичного підходу, але також можна відзначити те, що автор не вказує на потребу оперативного аналізу впровадження стратегії розвитку суб'єкта галузі на певному проміжку часу, результати якого можуть дати змогу внести корективи в стратегічний план розвитку.

По-друге, існують наукові підходи оцінки ефективності, основані на засадах порівняльного аналізу прогнозних та фактичних результатів впровадження стратегії, які передбачають визначення відповідного очікуваного ефекту. В контексті цих підходів часто використовують перелік показників першого наукового підходу, зокрема, можуть на умовах порівняльного аналізу оцінюватись виробничі, техніко-економічні, фінансові, соціальні показники розвитку суб'єкта галузі, але існують і інші оціночні індикатори, які застосовують в рамках вказаного напрямку.

\section{3. Підхід на основі класифікації основних напрямків порівняльної оцінки ефективності стратегій розвитку економічних суб'сктів}

Відповідно до другого наукового підходу можна запропонувати розглянути положення дослідження I. Гуркова [3, с. 205], присвячені класифікації основних напрямків порівняльної оцінки ефективності стратегій розвитку економічних суб'єктів. Згідно з твердженням автора, до основних напрямків порівняльної оцінки ефективності стратегій розвитку суб' єктів галузі можна віднести, зокрема:

1) напрямок оцінки ефективності реалізації окремих стратегічних проектів, здійснюваний за наступною схемою, яка передбачає етапи:

- порівняння фактичної звітної вартості реалізації стратегічного проекту відносно до прогнозної бюджетної вартості;

- порівняння фактичних строків реалізації стратегічного проекту відносно планових показників;

- порівняння фактичного звітного ефекту від реалізації стратегічного проекту у порівнянні з прогнозними даними за цим параметричним показником;

- визначення незапланованих додаткових (непрямих) ефектів, які виникли при реалізації стратегічного проекту. Варто відмітити, що автор вказує тільки на можливі додаткові ефекти від реалізації стра- 
тегічного проекту, але не актуалізує необхідність оцінки додаткових негативних впливів, які не були заплановані, але забезпечили недотримання стратегічних орієнтирів. Остання група показників (додаткові незаплановані негативні впливи, які обумовили недотримання стратегічних орієнтирів), на нашу думку, може бути включена в структуру оціночних показників ефективності розвитку суб'єкта галузі.

Слід відзначити, що окремі стратегічні проекті, судячи з положень літератури із стратегічного аналізу [10], можна оцінювати також 3 позицій інвестиційного аналізу, оскільки всі вони передбачають певне інвестування. Відповідно, за даним напрямком в якості основних оціночних показників ефективності використовують показники економічної ефективності інвестиційних проектів, які розраховують, переважно, на підготовчій стадії, зокрема, внутрішню норму доходності, чисту дисконтовану вартість проекту, індекс доходності інвестицій та витрат (або рентабельність інвестицій), строк окупності тощо;

2) напрямок оцінки ступеню досягнення прогнозних стратегічних цілей економічного суб'єкта, яка пов'язана із вивченням рівня досягнення прогнозних показників діяльності бізнесу (на рівні довго- та середньостроковій основі). Аналіз наукових матеріалів [3; 17] свідчить, що для вказаного виду оцінки можна використовувати:

- систему локальних показників, а саме, результат від конкретного проекту, якщо такий стратегічний проект здійснюється окремо від основної діяльності (вся система управління цим проектом впроваджена на рівні окремого підрозділу, до функціонування якого не були задіяними інші структурні одиниці) і показники його результативності та ефективності можна визначити окремо, і існують доступні інформаційні матеріали для проведення такого аналізу. Слід відмітити, що на практиці мало таких прикладів, оскільки стратегічний розвиток всього суб'єкта господарювання забезпечується саме в рамках основної діяльності, тобто, найбільш визначальною в розрізі ефективності виступає стратегія діяльності по підприємству в цілому. Отже, система локальних показників може мати широку практику застосування більшою мірою для дочірніх підприємницьких структур, в яких встановлена автономна система управління, підпорядкована тільки на вищому рівні головному підприємству, і окремих суб'єктів господарювання, що мають юридичну самостійність від головного мережевого підпри- 
ємства, i, які забезпечують високі результати діяльності. В будівельній галузі України, наприклад, це може бути ПрАТ «Домобудівний комбінат № 4», яке займало четверте місце серед тринадцяти найбільших підприємств (об'єднань підприємств) в сфері житлового будівництва України в 2018 р., і виступає структурним елементом Корпорації «ДБК-ЖИТЛОБУД» [11];

- систему збалансованих показників, пов'язаних з оцінкою результативності та ефективності реалізації комплексних стратегій розвитку на загальному рівні функціонування суб'єктів досліджуваної галузі. Тобто, в даному випадку передбачено оцінку основних оціночних показників за всіма сферами діяльності економічних суб'єктів за наслідками впровадження стратегій розвитку. Автори не визначають конкретного переліку оціночних показників ефективності реалізації комплексних стратегій розвитку суб'єктів господарювання. Отже, до категорії таких показників можуть бути віднесені ті, що в найбільшій мірі характеризують результати, ефект стратегічного управління, i за якими існують інформаційні дані на рівні досліджуваних підприємницьких структур. Вивчення наукових джерел [17, с. 121-122] свідчить, що використання збалансованої системи оціночних показників, пов'язаних $з$ оцінкою результативності та ефективності реалізації комплексних стратегій розвитку на загальному рівні функціонування суб'єктів досліджуваної галузі, має:

більше переваг, серед яких: можливість використання оперативного та стратегічного аналізу на різних рівнях впровадження стратегій, оскільки у суб'єкта діяльності існують аналітичні інформаційні джерела впровадження стратегії як на оперативному рівні (рівні впровадження стратегії на певному проміжку часу за внутрішньофірмовими даними, даними звітності за певні періоди тощо), так і на стратегічному рівні кінцевого впровадження стратегії; можливість повного контролю впровадження стратегії розвитку за всіма структурними одиницями суб'єкту підприємництва, так званого контролю «зверху вниз» (вертикальна система контролю); можливість впровадження на загальному корпоративному рівні нових оціночних параметричних показників в рамках стратегічних карт, які дадуть нові характеристики результативності та ефективності впровадження стратегій розвитку тощо; 
аніж недоліків, в складі яких виокремлюються: факт відсутності можливості вирішення вузьких питань, пов'язаних 3 оцінкою специфіки реалізації певних стратегічних завдань; ієрархічна вертикальна система оцінки впровадження стратегії розвитку гальмує ініціативи на рівні кожного окремого структурного підрозділу суб'єкта галузі тощо;

3) напрямок оцінки ступеню відповідності прогнозних стратегічних цілей економічного суб'єкта інтересам стейклолдерів (з англ. stakeholder) (зацікавлених осіб)), представлених, за твердженням автора, державою, постачальниками, кредиторами. Відповідно до положень наукового дослідження М. Ходоровського, Є. Алєксєнко [16], кожна зацікавлена особа, пов'язана з функціонуванням суб'єкта галузі зацікавлена в ресурсному обміні з останнім, зокрема, держава - в надходженні грошових ресурсів у вигляді податків та зборів від функціонування, кредитори - в ефективному ресурсному обміні 3 підприємницькою організацією, а саме, наданні кредитів, отриманні його повернення в повному обсязі з відповідними відсотками за користування, постачальники - в ефективному ресурсному обміні 3 підприємницькою організацією, а саме, постачанні продуктів (сировини), послуг, отриманні оплати за товар (послугу) тощо. Потрібно відзначити, що коло зацікавлених осіб може бути різним і залежати від напрямків діяльності суб’ єктів діяльності.

\section{4. Підхід в рамках порівняльної, динамічної, комплексної системи показників}

По-третє, слід відзначити науковий підхід до оцінки ефективності стратегій розвитку суб'єктів галузі, сформульований в рамках порівняльної, динамічної, комплексної системи показників, які ідентифікують ефективність за основними результатами щодо кожного з стратегічних напрямків управління. В контексті вказаного наукового підходу передбачено порівняльну, постійну оцінку виконання планових стратегічних орієнтирів за кожним 3 напрямків діяльності, зокрема, житлове будівництво, нежитлове будівництво, будівництво та ремонт інженерної інфраструктури, здійснюване в рамках одного підприємства (об'єднання підприємств) тощо.

В розрізі вказаного третього наукового підходу можемо розглянути трактування методики оцінки ефективності впровадження стра- 
тегії розвитку суб'єкта підприємництва, представлене Е. Доржиєвою [4, с. 116-118], орієнтований на аналіз в умовах інноваційного розвитку корпорації, але, на нашу думку, може бути використаний до будь-якого підприємства, що веде різні види діяльності в одній галузі, зокрема, будівельній. Згідно з авторським підходом, методика оцінки ефективності впровадження стратегії розвитку суб'єкта інноваційної діяльності (будь-якого підприємства, яке веде декілька видів діяльності в одній галузі) передбачає наступні етапи дослідження, зокрема:

1) вибір показників оцінки ефективності реалізації інноваційної стратегії (стратегії розвитку) економічного суб'єкта. Пропонується із застосуванням аналізу пріоритетів або факторного аналізу визначити найбільш важливі показники за кожним 3 напрямків діяльності за фінансовою, споживацькою, ризиковою, процесною складовою, складовою навчання та розвитку персоналу підприємства. Вказаний перелік більшою мірою орієнтований на інноваційну складову, зокрема, забезпечення компоненти інноваційного рівня знань та навичок співробітників, яка сприяє покращенню рівня впровадження стратегії розвитку підприємства. Отже, у разі, якщо суб'єкт підприємництва має інші цільові орієнтири, зокрема, інновації в сфері створення будівельної продукції (послуг), то визначають такі показники, які дозволяють оцінити зазначений аспект. Щодо кожної із оціночних сфер (фінансовою, споживацькою, ризиковою, процесною складовою, складовою навчання та розвитку персоналу підприємства) за кожним з стратегічних напрямків відповідно до пропозиції авторки можна обрати по три показники результативності (ефективності). Встановлення даних показників можна закріпити на рівні стратегічного прогнозу досліджуваного підприємства (об'єднань підприємств);

2) визначення планових (нормативних) значень обраних показників за оціночними сферами за кожним 3 напрямків діяльності економічного суб'єкта. В рамках авторського дослідження не зазначається порядок реалізації даного етапу методичного підходу. Але можемо припустити, що нормативні значення за оціночною фінансовою сферою за всіма напрямками діяльності суб'єкта галузі встановлюють виходячи 3 положень фінансово-економічного аналізу (зокрема, в частині визначення нормативного значення показників рентабельності, ліквідності, платоспроможності, фінансової стійкості, фінансової 
незалежності тощо). Стосовно інших оціночних сфер за всіма напрямками діяльності суб'єкта галузі (споживацької, ризикової, процесної складової, складової навчання та розвитку персоналу підприємства та інших, обраних відповідно до потреб аналізу) можна запропонувати керуватись виключно власними інтересами розвитку. Нормативні (прогнозні) значення показників за цими сферами потрібно визначати 3 огляду на характер та зміст стратегії розвитку, особливо це стосується стратегій, сформульованих під кутом орієнтиру на життєвий цикл суб'єкта галузі, продукції (послуг), ринку тощо. Відповідно, економічні суб'єкти, націлені на активно-наступальні інноваційні дії щодо ринку, конкурентоспроможності, продукції (послуг) можуть в якості стратегічних орієнтирів керуватись високими межами показників за вказаними оціночними сферами, а підприємства, що функціонують відповідно до менш прогресивних стратегічних дій та курсу будуть визначати нормативні значення вказаних показників на меншому рівні порівняно з інноваційно налаштованими конкурентами;

3) визначення фактичних (звітних) значень обраних показників за оціночними сферами за кожним з напрямків діяльності економічного суб'єкта. Вказана процедура може бути реалізована шляхом отримання інформаційних звітних та аналітичних даних за результатами діяльності суб'єкта підприємництва з фінансової звітності, внутрішньофірмових звітних даних тощо. Якщо такий аналіз здійснюється за результатами звітного року (років), передбачено використання фінансової та корпоративної звітності за вказаний період, за даними кварталів, півріччя, 9 місяців - дані фінансової звітності обмеженого переліку, внутрішньофірмові дані тощо. В рамках підбору фактичних (звітних) значень обраних показників за оціночними сферами за кожним 3 напрямків діяльності економічного суб'єкта рекомендовано їх групування, системне представлення;

4) визначення динаміки кожного з показників за кожною сферою та напрямком діяльності, встановлення їх вагових значень та виділення вагових значень для кінцевої оцінки ефективності за кожною із оціночних сфер. Встановлення вагових значень передбачено здійснювати із застосуванням аналізу пріоритетів (пріоритетного значення показників за обраною оціночною сферою та напрямком діяльності) [7]. Традиційно вагові коефіцієнти визначаються в межах від 0,1 до 1. Слід 
відмітити, що Е. Доржиєва [4, с. 120] пропонує наступний розподіл вагових значень для:

- фінансової сфери (компоненти) на рівні 0,1 ;

- ризикової компоненти - на рівні 0,3;

- споживацької компоненти - на рівні 0,1 ;

- процесної компоненти - на рівні 0,3;

- компоненти навчання та розвитку персоналу підприємства - на рівні 0,2 .

Представлений підхід до встановлення вагових значень за основними оціночними сферами за основними стратегічними напрямками діяльності суб'єкта галузі, на нашу думку, є дещо дискусійним, оскільки у деяких підприємницьких структур фінансова компонента часто стоїть на першому місці, i, відповідно може мати найвищий рівень, це саме стосується ринкової складової, на яку не вказується в рамках досліджуваного авторського підходу. Але, дана наукова пропозиція орієнтована на певний аспект забезпечення ефективності впровадження стратегії розвитку, а саме, на інноваційну складову високого рівня знань та навичок співробітників компанії. У підприємств, націлених на інші стратегічні орієнтири розподіл вагових значень за оціночними сферами може бути іншим, сформульований в контексті їх пріоритетів розвитку;

5) розрахунок та оцінка загального рівня ефективності впровадження стратегії розвитку суб'єкта галузі, який визначається через встановлення суми ефектів за комплексними показниками за кожною 3 оціночних сфер, скоригованих на вагові значення, за всіма напрямками стратегічного розвитку. Згідно з підходом Е. Доржиєвої [4, с. 117-118], пропонується використання нормативних значень загального рівня ефективності впровадження стратегії розвитку суб'єкта галузі, які передбачають ідентифікацію:

позитивного характеру стратегічного управління за всіма стратегічними напрямками розвитку підприємства, якщо отриманий показник більше 1. Відповідно до твердження авторки, спостерігається ефективність за всіма стратегічними напрямкам розвитку, констатується ефективність, і у разі оперативної оцінки - приймається рішення про подальше незмінне виконання стратегічних орієнтирів, у разі оцінки за результатами впровадження стратегії - формулюються загальні висновки та перспективи для подальшого стратегічного планування тощо; 
нейтрального характеру стратегічного управління за всіма (певним) стратегічними напрямками розвитку підприємства, якщо отриманий показник дорівнює 1. Відповідно до авторського підходу, в разі виявлення такого значення, необхідне коригування показників стратегічного розвитку, якщо оцінка здійснювалась на оперативному рівні в процесі проміжної реалізації стратегії;

негативного характеру стратегічного управління за всіма (певним) стратегічними напрямками розвитку підприємства, якщо отриманий показник менше 1. У разі, якщо виявлено таке значення на оперативному рівні в процесі проміжної реалізації стратегії можливо здійснити перегляд стратегії розвитку за всіма напрямками (або у разі можливості - певним напрямком) розвитку суб'єкта галузі. Якщо неефективність демонструється за певним напрямком, наприклад, невиконання або негативні наслідки від впровадження стратегії на певному відрізку часу, можлива розробка адаптаційних, антикризових заходів, які не вплинуть на реалізацію інших ефективних напрямків діяльності.

\section{5. Підхід у вигляді багатоаспектної категорії, що включас ефекти за різними сферами без підведення їх до комплексного сдиного показника}

По-четверте, заслуговує на вивчення науковий підхід до оцінки ефективності стратегій розвитку суб'єктів галузі, представлений у вигляді багатоаспектної категорії, що включає ефекти за різними сферами без підведення їх до комплексного єдиного показника. На користь такого підходу висловлюються А. Казанцев, Л. Мінделлі [8, с. 385], які наголошують на неправомірності спроб підсумовувати значення окремих компонентів стратегічного розвитку, наведення єдиного показника, який би демонстрував загальну ефективність від впровадження інноваційних стратегій. Окремо дослідники пояснюють, що мається на увазі неприйнятність характеризувати загальну ефективність щодо тих компонент, критерії та показники яких не сумісні у вимірюваних оціночних параметрах іншим. Тобто, ті показники ефективності за певними оціночними компонентами, які можна вимірювати в кількісних параметрах, безумовно, можуть подаватись як окремо, так і спільно з іншими, а за якісними ефектами рекомендовано визначати характеристику результативності у тих значеннях, які можуть бути представлені на екс- 
пертному рівні. Вказане твердження, на нашу думку, є достатньо дискусійним, існують певні підходи до визначення рейтингів ефективності підприємств галузі, в тому числі будівельної, в яких на об'єктивному, науково обгрунтованому рівні подано оціночні показники діяльності, які не викликають заперечення. Але також слід відзначити, що використання тільки кількісних оціночних показників за компонентами діяльності (фінансовою, ринковою, кадровою, виробничою, процесною, технологічною, інноваційною тощо) дасть більш достовірний результат, який буде чітко визначати певний рівень ефективності від впровадження стратегії розвитку суб' єкта галузі. За певними компонентами, що визначаються через якісні показники або кількісно-якісні показники, у разі відсутності чіткого співставлення з кількісними показниками може бути проведена окрема оцінка стану ефективності впровадження стратегії розвитку суб'єкта підприємництва.

В контексті четвертого наукового підходу можемо дослідити визначення методики оцінки ефективності впровадження стратегій розвитку суб'єктів галузі (на прикладі інноваційних стратегій), визначеної Ю. Ефімичевим, О. Трофімовим [5, с. 32-37] через їх розрахунок, вивчення та аналіз на рівні окремих структурних компонент діяльності. Відповідно до авторського підходу, для визначення ефективності від впровадження інноваційної стратегії розвитку суб'єкта галузі можна розрахувати ефекти за такими структурними компонентами, зокрема:

1) Економічний компонент, який передбачає оцінку: раціонального використання ресурсів; збільшення економічних цінностей підприємницької структури (капіталу, активів); збільшення динаміки росту за показниками результативності (доходом (виручкою) від реалізації продукції (послуг), чистим доходом (виручкою) від реалізації продукції (послуг); збільшення динаміки обсягів валового прибутку, чистого прибутку; загальної економічної ефективності за показника інвестицій, залучених для реалізації інноваційної стратегії розвитку (інтегрального ефекту, індексу рентабельності, періоду окупності інвестицій у впровадження інноваційної стратегіï). Потрібно відмітити, що автори в рамках визначення напрямків оцінки вказують на необхідність окремого аналізу економічної ефективності за: впровадженням науково-технічних розробок, націлених на створення прогресивних технологічних процесів, підвищення рівня автоматизації 
та механізації виробництва (ефект в сфері виробництва); виробництвом та впровадженням нових видів продукції з покращеними технологічними параметрами (ефект в сфері споживання). Можна стверджувати, що окрема оцінка ефективності за такими напрямками інноваційного стратегічного розвитку може передбачати лише визначення окремих показників ефективності. Також слід відзначити, що в розрізі оцінки загальної економічної ефективності автори не передбачають традиційний підхід щодо вивчення загальних показників рентабельності (рентабельності активів, рентабельності продукції, рентабельності власного капіталу тощо, а концентруються лише на інвестиційному підходу до аналізу ефективності інвестицій в сфері впровадження та реалізації інноваційних стратегій розвитку. Відповідно, таке обмеження не забезпечує комплексної картини загальної економічної ефективності за результатами впровадження стратегій розвитку підприємницької структури. Відповідно до бачення Ю. Ефімичева, О. Трофімова [5, с. 32-36], економічна ефективність цікава тільки з точки зору повернення та ефекту від інвестиційної діяльності, націленої на впровадження стратегії, а сам результат реалізації останньої не цікавий з точки зору такого аналізу. Але, можемо стверджувати, що такий підхід не дасть відповіді про важливі економічні аспекти впровадження самої інноваційної стратегії розвитку, такі як рентабельність витрат, рентабельність продукції, загальна рентабельність діяльності від впровадження основної стратегії розвитку суб'єкта підприємництва (стосовно дослідження вказаних науковців - інноваційної стратегії розвитку підприємства). Слід відмітити, що показники економічного компоненту діяльності від впровадження стратегії розвитку передбачають використання виключно кількісних параметричних показників аналізу за даним напрямком;

2) Науково-технічний компонент, який передбачає оцінку: приросту інформаційних даних, що використовуються суб' єктом галузі, іншими учасниками ринку; приросту нових знань за різними сферами, в тому числі у виробництві. Автори вказують на неможливість кількісного виміру ефективності за вказаним компонентом. За їх твердженням в даному випадку можливе використання експертного методу оцінки із застосуванням шкали характеристик, серед яких пропонується виділення, зокрема: 
- показника рівня новизни. Ймовірно, мається на увазі новизна продукції (послуг), виробництва. Як приклад, в стратегії розвитку ПрАТ «ХК «Київміськбуд» 6 ; 9; 12] визначено впровадження новітніх технологій будівництва, розроблених компанією, які фактично реалізуються компанією. Зазначені технології грунтовно визначені в технологічному плані та звіті з відповідною калькуляцією використання нових технологій, технологічного обладнання, витратами на їх створення (придбання) тощо;

- показника можливості практичної реалізації новітніх технологій, розроблених, апробованих досліджуваним суб'єктом галузі. Якщо підприємство самостійно розробляє, реєструє нову технологію, формується відповідна технологічна документація, яка буде створена лише за умов існування можливості практичної реалізації новітніх технологій. Така оцінка передбачає залучення експертів, але за умов відкритості компанії щодо просування цієї технології, буде існувати відповідна технологічна документація, і покупець цієї розробки зможе чітко визначити можливість їі використання. Слід відмітити, що якщо вказана технологія має комерційну цінність, передбачено можливість трансферу, існує перспектива експорту технологій, що є позитивним для інтересів держави;

- показника можливого масштабу застосування новітніх технологій, розроблених, апробованих досліджуваним суб'єктом галузі. Мається на увазі, наприклад, чітка оцінка можливості застосування певної технології будівництва у відповідних географічних, кліматичних умовах тощо. Вказаний показник може бути оцінений на основі вивчення технологічних карт щодо конкретної технології;

- показника перспективності використання новітніх технологій, розроблених, апробованих досліджуваним суб'єктом галузі. Оцінка за вказаним напрямком передбачає проведення експертного аналізу в сфері технології, маркетингу ринку відповідної галузі тощо.

Можемо відмітити, що в рамках аналізу ефективності впровадження стратегії розвитку за науково-технічним компонентом можливе використання кількісного показників, який ідентифікують рівень витрат на інноваційний (науково-технічний розвиток) та рівень результативності таких витрат (рентабельності інвестицій в інноваційний розвиток). В такому випадку може здійснюватись оцінка за вказаним напрямком із застосуванням тільки кількісних оціночних показників, 
для розрахунку яких не потрібне залучення зовнішніх експертів, i які дають достовірну картину щодо досліджуваної проблематики.

3) Соціальний компонент, який передбачає оцінку: ефектів від впровадження стратегії розвитку на рівні суб'єкта галузі, регіону, інших територій тощо. Автори [5, с. 36-37] пропонують оцінювати ці ефекти із застосуванням переважно якісних показників серед яких, зокрема: покращення житлових та культурно-побутових умов (у разі масового розвитку житлового та нежитлового будівництва, будівництва інженерної інфраструктури); покращення рівня здоров'я людей (якщо впроваджується стратегія, орієнтована на охорону здоров'я, покращення екології зовнішнього середовища тощо); збільшення вільного часу людей із збереженням відповідного рівня доходів (у разі використання інноваційних технологій виробництва суб'єкта галузі, орієнтованого на підтримання кадрового потенціалу); зміна структури кадрового потенціалу в бік підвищення його кваліфікації за рахунок суб'єкта галузі; покращення рівня зайнятості в рамках певних територій. На нашу думку, соціальний компонент може оцінюватись також iз застосуванням кількісних показників, за допомогою яких можна оцінити інвестиції в розвитку кадрового потенціалу, ефект від таких інвестицій як для суб'єкта галузі, так і для працівників (через покращення рівня доходів, житлових умов тощо).

4) Екологічний компонент, який передбачає оцінку ефекту покращення основних показників екологічного середовища від впровадження стратегій розвитку суб'єктів галузі. Серед таких показників автори [5, с. 37] пропонують оцінювати традиційні для екологічного аналізу показники рівня шуму, електромагнітного поля, забрудненості повітря, освітленості, вібрацій тощо. Оцінка ефекту за цим компонентом, особливо за рівнем шуму із зовнішнього середовища (вулиці, суміжних квартир та кімнат) $є$ важливим для вивчення ефективності впровадження новітніх технологій будівництва житлових та нежитлових будівель. Акцент на зниженні рівня шуму в житлових та нежитлових приміщеннях $є$ окремим конкурентним фактором для підприємств будівельної галузі в сучасних умовах містобудування, пошуку високоефективних засобів шумоізоляції в умовах крупних мегаполісів.

Можемо констатувати, що підхід Ю. Ефімичева, О. Трофімова [5, с. 32-37] має високу наукову цінність, може за умов певної адап- 
тації бути використаний при розробці методичного підходу до оцінки ефективності стратегії розвитку суб'єкта будівельної галузі України на сучасному етапі функціонування.

\section{6. Підхід у формі трьохмірної моделі ефективності, що враховує якість прогнозної стратегії розвитку, якість механізму реалізації стратегії розвитку та рівень стратегічної ефективності}

По-п'яте, існує науковий підхід до оцінки ефективності стратегій розвитку суб'єктів галузі, сформульований у формі трьохмірної моделі ефективності, що враховує якість прогнозної стратегії розвитку, якість механізму реалізації стратегії розвитку та рівень стратегічної ефективності. Зазначений підхід представлений в рамках положень наукового дослідження К. Шишкової [18]. Згідно з авторським підходом передбачено оцінювати:

- якість прогнозної стратегії розвитку суб'єкта галузі за відносними показниками, що характеризують: відповідність стратегії умовам зовнішнього середовища, його тенденціям та змінам; гнучкість; контроль; відповідність можливостям суб'єкта діяльності; об'єктивність; грунтовність тощо;

- якість механізму реалізації стратегії розвитку підприємницької структури за рівнем: механізму побудови, реалізації, оцінки, контролю стратегії; доступності реалізації; повноти та максимального впровадження основних стратегічних завдань;

- рівень стратегічної ефективності за основними якісними змінами оптимізації результативності розвитку суб'єкта галузі. Пропонується розрахунок окремого інтегрального показника стратегічної ефективності;

- інтегрального показника ефективності стратегії розвитку за трьохмірною системою вказаних оціночних координат (якість прогнозної стратегії розвитку, якість механізму реалізації стратегії розвитку та рівень стратегічної ефективності).

Можна констатувати, що вказаний науковий підхід якісно відрізняється від попередніх тим, що враховує якісні зміни від стратегічного прогнозування, якісний рівень механізму реалізації стратегії розвитку та стратегічну ефективність впровадження обраного курсу для досліджуваного суб'єкта галузі. Розглянутий методичний підхід може, на нашу думку, бути використаний до умов будь-якої галузі в сучасних умовах розвитку. 
По-шосте, можна відмітити наукові підходи, що передбачають оцінку стратегій розвитку за окремими критеріями ефективності. Такий підхід має ознаки локального щодо системи оцінки ефективності розвитку досліджуваного суб'єкта.

В рамках шостого наукового підходу слід розглянути положення дослідження А. Томпсона, А. Стрікленда [19]. Згідно з підходом авторів, основними оціночними критеріями оцінки ефективності стратегій розвитку суб' єктів галузі можуть виступати:

1) ступінь відповідності стану готовності досліджуваного підприємства до впливів внутрішніх, зовнішніх факторів з позицій власних стратегічних цільових орієнтирів, потенціалу можливостей тощо. Оцінка даного критерію дає відповідь на питання готовності, неготовності до впровадження певної стратегії розвитку, сумнівності іiі реалізації за фактичних умов;

2) рівень конкурентних переваг, визначений на стратегічному рівні. Встановлено, якщо конкурентні переваги високі, стратегія розвитку характеризується суттєвим рівнем ефективності, потужності тощо;

3) рівень ефективності результатів впровадження стратегій, який характеризує стан інтенсивності функціонування досліджуваного суб'єкта. Вивчення вказаного критерію можливе із використанням традиційних підходів до оцінки прибутковості, інших фінансово-економічних показників тощо.

Незважаючи на незначний перелік оціночних критеріїв, їх розрахунок та аналіз може дати чітке уявлення щодо загального стану ефективності стратегії розвитку досліджуваного суб'єкта. Отже, такий підхід може бути використаний для потреб експрес-аналізу за вказаним напрямком.

\section{7. Висновки}

Вивчення наукових підходів щодо проблеми оцінки ефективності стратегії розвитку суб' єктів галузі дозволило встановити, що на сучасному етапі розвитку економічної науки відсутній універсальний, науково обгрунтований підхід, який би не викликав дискусій з боку тих або інших вчених, дослідників. Існують наукові підходи, що передбачають можливість вивчення інтегрального показника, представленого кількісними та якісними оціночними показниками, є такі, що виклю- 
чають можливість суміщення кількісного та якісного аналізу, в певних положеннях наукових праць висуваються пропозиції використання локального аналізу за певними оціночними критеріями, висуваються пропозиції багатоаспектного аналізу із підсумками результатів ефективності за окремими компонентами та напрямками впровадження стратегії. Виходячи з вищезазначеного, можна відзначити, що для розробки методичного підходу оцінки ефективності стратегії розвитку суб'єкта будівельної галузі буде обрано такий склад показників, які не передбачатимуть дискусійних поглядів щодо грунтовності, доцільності, достовірності та об'єктивності. Відповідно, це будуть кількісні параметричні показники з відповідними нормативними оціночними критеріями щодо стратегії розвитку суб'єкта досліджуваної галузі.

\section{Список літератури:}

1. Бойко Ю.А. Методика оценки стратегического планирования на предприятии. Оценка эффективности стратегического планирования на промышленном предприятии. Российское предпринимательство. 2009. № 5(1). С. 32-41.

2. Гудзь О.І., Мусійовська О.Б. Методичний підхід до обгрунтування стратегії розвитку підприємства. Економіка та управління підприємствами. 2018. Вип. 22. С. 334-340.

3. Гурков И.Б. Стратегический менеджмент организации. Москва : ТЕИС, 2004. $239 \mathrm{c}$.

4. Доржиева Э.Л. Формирование и реализация инновационной стратегии развития промышленных корпораций : дис. ... канд. екон. наук : 08.00.05. Иркутск, 2014. 144 с.

5. Ефимычев Ю.И., Трофимов О.В. Концептуальные основы стратегии инновационного развития промышленных предприятий. Н. Новгород : Изд-во ННГУ им. Н.И. Лобачевского, 2010. 273 с.

6. Звіти Київміськбуд. URL: https://kmb.ua/ua/about/corporate-information/ otchety/ (дата звернення: 08.06.2019).

7. Казакова Н. Современный стратегический анализ. Москва : Изд-во Юрайт, 2017. 386 с.

8. Казанцев А.К., Минделли Л.Э. Основы инновационного менеджмента. Москва : Экономика, 2004. 475 с.

9. Київміськбуд. Річний звіт 2018. URL: https://kmb.ua/wp-content/ uploads/2019/06/kmb_3105.pdf (дата звернення: 08.06.2019).

10. Никонова И.А. Проектный анализ и проектное финансирование. Москва : Альпина Паблишер, 2012. 154 с.

11. Приватне акціонерне товариство «Домобудівний комбінат № 4». URL: https://smida.gov.ua/db/participant/05503160 (дата звернення: 08.06.2019). 
12. Приватне акціонернетовариство «Холдингова компанія «Київміськбуд». URL: https://kmb.ua/ua/?gclid=Cj0KCQjwov3nBRDFARIsANgsdoHhg_o2vlO puGCehwYuwAI0jU_n_3EjyQHIgTupcWklL4wQY1dNBDAaAjpvEALw_wcB (дата звернення: 08.06. 2019 ).

13. Ратинська I.C. Удосконалення стратегічного планування діяльності державних акціонерних товариств України. Вісник НАДУ при Президентові України. 2016. № 1. С. 87-93.

14. Самуляк В.Ю., Фещур Р.В. Оцінювання рівня розвитку підприємств. Вісник НУ «Львівська політехніка». 2008. № 633. С. 627-636.

15. Фещур Р.В., Самуляк В.Ю. Групи показників (індикаторів) оцінювання рівня розвитку підприємств. Вісник НУ «Львівська політехніка». 2010. № 691. С. 231-239.

16. Ходоровский М.Я., Алексенко Е.В. Подходы к оценке эффективности стратегии организации. Вестник УГТУ-УПИ. 2009. № 3. С. 4-21.

17. Хорват П. Сбалансированная система показателей как средство управления предприятием. Проблемы теории и практики управления. 2000. № 4. C. 118-122.

18. Шишкова Е.А. Способы оценки эффективности реализации стратегии развития компании. Экономический журнал. 2012. № 26. С. 111-117.

19. Thompson A.A., Strickland A. J. Strategic management concepts and cases. Boston McGraw-Hill / Irwin, 2003. 1049 p.

\section{References:}

1. Bojko Ju.A. (2009). Metodika ocenki strategicheskogo planirovanija na predprijatii. Ocenka jeffektivnosti strategicheskogo planirovanija na promyshlennom predprijatii [Methodology for assessing strategic planning at the enterprise. Evaluation of the effectiveness of strategic planning at an industrial enterprise]. Russian business, no. 5(1), pp. 32-41.

2. Hudz O.I., Musijovska O.B. (2018). Metodychnyj pidxid do obhruntuvannya stratehiyi rozvytku pidpryyemstva [Methodical approach to substantiation of enterprise development strategy]. Business Economics and Management, no. 22, pp. 334-340.

3. Gurkov I.B. (2004). Strategicheskij menedzhment organizacii [Organization strategic management]. Moskva: TEIS. (in Russian)

4. Dorzhieva Je.L. (2014). Formirovanie i realizacija innovacionnoj strategii razvitija promyshlennyh korporacij [Formation and implementation of an innovative development strategy for industrial corporations] (PhD Thesis), Irkutsk.

5. Efimychev Ju.I., Trofimov O.V. (2010). Konceptual'nye osnovy strategii innovacionnogo razvitija promyshlennyh predprijatij [Conceptual foundations of the strategy for innovative development of industrial enterprises]. N. Novgorod: Izd-vo NNGU im. N.I. Lobachevskogo. (in Russian)

6. Zvity Kyyivmiskbud [Reports of the City of Kyiv]. Retrieved from: https://kmb.ua/ua/about/corporate-information/otchety/ (accessed 08.06.2019).

7. Kazakova N. (2017). Sovremennyj strategicheskij analiz [Modern strategic analysis]. Moskva: Izd-vo Jurajt. (in Russian) 
8. Kazancev A.K., Mindelli L.Je. (2004). Osnovy innovacionnogo menedzhmenta [Fundamentals of Innovation Management]. Moskva: Jekonomika. (in Russian)

9. Kyyivmiskbud. Richnyj zvit, 2018 [Kyivmiskbud. Annual Report, 2018]. Retrieved from: https://kmb.ua/wp-content/uploads/2019/06/kmb_3105.pdf (accessed 08.06.2019).

10. Nikonova I.A. (2012). Proektnyj analiz i proektnoe finansirovanie [Project Analysis and Project Financing]. Moskva: Al'pina Pablisher. (in Russian)

11. Pryvatne akcionerne tovarystvo «Domobudivnyj kombinat № 4» [Private Joint-Stock Company «House-Building Plant No. 4»]. Retrieved from: https://smida.gov.ua/db/participant/05503160 (accessed 08.06.2019).

12. Pryvatne akcionerne tovarystvo «Xoldynhova kompaniya «Kyyivmis»kbud» [Private Joint Stock Company «Kyivmiskbud Holding Company»]. Retrieved from: https://kmb.ua/ua/?gclid=Cj0KCQjwov3nBRDFARIsANgsdoHhg_o2vlOpu GCehwYuwAI0jU_n_3EjyQHIgTupcWklL4wQY1dNBDAaAjpvEALLw_wcB (accessed 08.06.2019).

13. Ratynska I.S. (2016). Udoskonalennya stratehichnoho planuvannya diyal»nosti derzhavnyx akcionernyx tovarystv Ukrayiny [Improvement of strategic planning of activity of state joint-stock companies of Ukraine]. NADU Bulletin under the President of Ukraine, no. 1, pp. 87-93.

14. Samulyak V.Yu., Feshhur R.V. (2008). Ocinyuvannya rivnya rozvytku pidpryyemstv [Assessment of the level of enterprise development]. Bulletin of $N U$ «Lviv Polytechnic», no. 633, pp. 627-636.

15. Feshhur R.V., Samulyak V.Yu. (2010). Hrupy pokaznykiv (indykatoriv) ocinyuvannya rivnya rozvytku pidpryyemstv [Groups of indicators for assessing the level of enterprise development]. Bulletin of NU «Lviv Polytechnic», no. 691, pp. 231-239.

16. Hodorovskij M.Ja., Aleksenko E.V. (2009). Podhody k ocenke jeffektivnosti strategii organizacii [Approaches to assessing the effectiveness of an organization's strategy]. Bulletin of USTU-UPI, no. 3, pp. 4-21.

17. Horvat P. (2000). Sbalansirovannaja sistema pokazatelej kak sredstvo upravlenija predprijatiem [Balanced scorecard as a means of enterprise management]. Problems of management theory and practice, no. 4, pp. 118-122.

18. Shishkova E.A. (2012). Sposoby ocenki jeffektivnosti realizacii strategii razvitija kompanii [Ways to assess the effectiveness of the implementation of the development strategy of the company]. The economic journal, no. 26, pp. 111-117.

19. Thompson A.A., Strickland A. J. (2003). Strategic management concepts and cases. Boston McGraw-Hill / Irwin. 